\title{
PEMASANGAN PEMANAS AIR BAK PEMBENIHAN IKAN BERBASIS ARDUINO DAN PLTS UNTUK MENINGKATKAN KETAHANAN PANGAN
}

\author{
I W Jondra', IGP Mastawan², I M Aryasa Wiryawan', I G Suputra \\ Widarma4, I G N A Dwijaya Saputra5 \\ 12345 Teknik Elektro (Politeknik Negeri Bali) \\ ${ }^{1}$ E-mail address wjondra@pnb.ac.id; 2 E-mail address mastawan@pnb.ac.id; 3 E-mail \\ address aryasa_w@pnb.ac.id; 4 E-mail address suputra@pnb.ac.id; 5 E-mail address \\ dwijaya s@pnb.ac.id
}

\begin{abstract}
The Covid-19 pandemic was accompanied by food security threat, due by economic disruptions. The pandemic and the winter is increasingly food security threat in Desa Lumbung, Selemadeg Barat, Tabanan, Bali. In Bali, winter usually occurs between July and November, it has an impact on the lower water temperature, which triggers the harvest failure of the fish seed, because the water temperature lower than 25 degrees celcius, but fish seed well grow up in the range of water temperature 25 to 30 degrees celcius.

The Department of Electrical Engineering of the State Polytechnic of Bali has carried out community service activities in Desa Lumbung. The activities is training to construction, operation and maintenance of arduino-based of water heaters for fish seed pond and solar power plants, which have been proven to be able to maintain water temperature. Even though in the winter the water temperature is maintained between 25 to 30 degrees celcius, it maintains the harvest of fish seeds every 45 days. The success of this harvest will support food security in Desa Lumbung.

Solar power plants are chosen as an energy source, because that is a green energy. This is in line with the Bali State Polytechnic as a center of excellent technology for green tourism. The output of this activities is proven, it must to be massive done and the government must increases the budget for the implementation. Food security is very important to maintain the stability of the Republic of Indonesia.
\end{abstract}

Keywords: winter, heater, food

\begin{abstract}
Abstrak
Dimasa pandemi covid-19 diiringi oleh ancaman ketahanan pangan, karena terganggunya perekonomian. Masa pandemi yang beriringan dengan musim dingin semakin mengancam ketahanan pangan di Desa Lumbung, Selemadeg Barat, Tabanan, Bali. Di Bali musim dingin biasanya terjadi antara bulan Juli
\end{abstract}


sampai dengan Nopember, berdampak pada dinginnya suhu air, yang memicu gagal panen benih ikan, karena temperatur air dapat mencapai di bawah 25 derajat celcius, sedangkan pembenihan ikan akan tumbuh dengan baik apabila temperatur air berkisar antara 25 sampai dengan 30 derajat celcius.

Jurusan Teknik Elektro Politeknik Negeri Bali melaksanakan kegiatan pengabdian kepada masyarakat di Desa Lumbung, dalam bentuk pelatihan pemasangan, pengoperasian dan pemeliharaan pemanas air bak pembenihan ikan berbasis arduino dan pembangkit listrik tenaga surya, telah terbukti mampu menjaga temperatur air dalam bak pembenihan ikan. Walaupun pada musim dingin temperatur air yang terjaga antara 25 sampai dengan 30 derajat celcius mempertahankan hasil panen benih ikan setiap 45 hari sekali. Keberhasilan panen ini akan menunjang ketahanan pangan di Desa Lumbung.

Dipilihnya pembangkit listrik tenaga surya sebagai sumber energi, karena energi surya merupakan energi yang ramah lingkungan. Hal ini sejalan dengan ditetapkannya Politeknik Negeri Bali sebagai pusat unggulan teknologi berbasis green tourism. Luaran hasil kegiatan ini perlu dilakukan secara masal karena sudah terbukti keberhasilannya dan pemerintah menambah anggaran untuk pelaksanaan kegiatan serupa. Ketahanan pangan merupakan suatu hal yang sangat penting untuk menjaga stabilitas Negara Kesatuan Repubik Indonesia.

Kata Kunci: dingin, pemanas, pangan

\section{PENDAHULUAN}

Desa Lumbung merupakan desa yang subur, terletak di ketinggian, memiliki jarak cukup jauh dari Kota Tabanan $20 \mathrm{~km}$, dan dari kota $45 \mathrm{~km}$ dari Kota Denpasar. Ketersediaan air cukup melimpah untuk keperluan pertanian, peternakan maupun untuk budi daya ikan. Jarak yang cukup jauh dari pusat kota mempersulit warga setempat untuk memperoleh makanan selain padi dan sayuran. Kalau pun ada yang menjual keliling, hantaman ekonomi sebagai dampak dari pandemic membuat daya beli masyarakat menjadi turun. Petani dan peternak sejak lama telah terpinggirkan oleh Rantai Pasokan Pangan, di mana berbagai korporasi membangun sistem rantai pasokan sejak dari hulu dan hilir yang terintegrasi secara vertikal dan horizontal untuk meminimalkan biaya dalam sebuah proses produksi (Setiawan, 2016 dalam Anggalih, 2020:89)

Alfin dan Fadil (2020:33) menyatakan sepanjang sejarah, pandemi merupakan salah satu fenomena global yang mampu secara luas mempengaruhi berbagai sektor, pertanian sebagai pilar ketahanan pangan tak luput dari disrupsi masif akibat pandemi, akibatnya, kelaparan menjadi isu laten yang kerap 
terjadi beriringan atau berkelanjutan dengan pandemi itu sendiri. Sejalan dengan pendapat Alfin dan Fadil tersebut, maka masyarakat di Dusun Dajan Sema, Desa Lumbung, Kecamatan Selemadeg Barat, Kabupaten Tabanan, merasakan bahwa pandemi covid-19 telah mempengaruhi perekonomian masyrakat. Banyak warga masyarakat yang sebelumnya bekerja di kapal pesiar, kerja swasta di kota Denpasar, kerja buruh di perusahaan pariwisata yang berada di sekitar daerah tersebut, akhirnya kembali pulang ke Desa untuk jangka waktu yang tidak tentu dan tidak memiliki mata pencaharian. Sebagaian dari mereka Kembali bekerja bertani, beternak, dan pembudidaya ikan.

Memanfaatkan alam sekitar untuk menjadi sumber makanan, untuk ketahanan pangan adalah salah satu upaya yang perlu dilakukan masyarakat setempat. Sa'dianoor, dkk (2020:89) menemukan bahwa masyarakat hendaknya tetap dapat mempertahankan hidup dengan adanya ketersediaan sumber makanan setempat. Ketersediaan makanan dari tumbuhan di Desa Lumbung cukup memadai untuk ketahanan pangan masyarakat setempat. Namun dari sisi lauk pauk akan menjadi masalah bagi masyarakat setempat. Untuk memenuhi kebutuhan lauk-pauk masyarakat setempat juga beternak dan melakukan budi daya ikan, seperti yang dilakukan oleh kelompok pembudi daya ikan "Mina Yukti".

Dalam melakukan budi daya ikan masyarakat setempat mengalami kendala pada musim dingin, sekitar Bulan Juli sampai dengan Nopember. Pada bulan ini temperatur air di daerah setempat dapat mencapai 18 derajat celcius. Ikan hasil budidaya baik pembenihan maupun pembesaran ikan, akan bisa berjalan baik apabila temperatur air berkisar 25 sampai dengan 30 derajat celcius (Parker, 2012 dalam Muarif, 2016:99).

Menghadapi permasalahan tersebut, maka tim pengabdian kepada masyarakat, Jurusan Teknik Elektro, Politeknik Negeri Bali, memutuskan perlunya sentuhan teknologi dalam membantu masyarakat kelompok pembudidaya ikan "Mina Yukti", di Dusun Dajan Sema, Desa Lumbung, Selemadeg Barat, Kabupaten Tabanan, Bali. Teknologi yang ditawarkan adalah Pemanas air yang dikontrol dengan Arduino. Penggunaan Arduino ini cukup baik digunakan untuk mengontrol suhu air (Khaidir, 2019:427). Pasokan sumber daya listriknya diambil dari sebuah pembangkit listrik tenaga surya (PLTS), karena ketersediaan sinar matahari di daerah tersebut cukup baik sepanjang tahun. 
Dengan adanya kegiatan "Pemasangan Pemanas Air Bak Pembenihan Ikan Berbasis Arduino dan PLTS Untuk Meningkatkan Ketahanan Pangan Di Masa Pandemi”, luaran yang diharapkan adalah dapat dilakukan pengaturan temperatur air bak pembenihan ikan sepanjang tahun, sehingga ketersediaan benih ikan sepanjang tahun dapat dilakukan oleh kelompok pembudidaya ikan. Ketersediaan benih ikan sepanjang tahun akan mendorong ketersediaan ikan sepanjang tahun. Tentu hal tersebut diharapkan mampu meningkatkan ketahanan pangan masyarakat di pedesaan, khususnya di Dusun Dajan Sema, Desa Lumbung, dan masyarakat di sekitarnya.

\section{METODE DAN PELAKSANAAN}

\section{Metode}

Pelaksanaan kegiatan Pengabdian Kepada Masyarakat dalam bentuk : Pemasangan Pemanas Air Bak Pembenihan Ikan Berbasis Arduino Dan PLTS Untuk Meningkatkan Ketahanan Pangan Di Masa Pandemi dilakukan dengan metode : pelatihan pemasangan dan pengoperasian pemanas air bak pembenihan ikan berbasis arduino dan pembangkit listrik tenaga surya kepada kelompok pembudidaya ikan "Mina Yukti.

\section{Pelaksanaan Kegiatan}

Kegiatan pengabdian kepada masyarakat ini dilakukan di : Dusun Dajan Sema, Desa Lumbung, Selemadeg Barat, Kabupaten Tabanan, Bali. Kegiatan ini dilaksanakan pada tanggal 16 Juli 2020.

Peserta kegiatan pengabdian kepada masyarakat adalah sebak 112 orang, yang terdiri atas : staf pengajar sebanyak 80 orang, mahasiswa Jurusan Teknik Elektro sebanyak 20 orang dan menyertakan beberapa Masyarakat anggota Kelompok Pembudidaya Ikan “Mina Yukti” sebanyak 12 orang.

\section{HASIL DAN PEMBAHASAN}

Pelaksanaan Pengabdian Kepada Masyarakat (PKM) ini dilaksanakan pada masa pandemi covid-19, dengan demikian pelaksanaannya dilakukan dengan memperhatikan protokol kesehatan. Karena dalam PKM ini terdapat pekerjaan konstruksi, maka dalam pelaksanaannya berpedoman kepada Protokol Pencegahan Covid-19 di Proyek Konstruksi(Trisasongko,2020). Panitia pelaksana menyusun protokol kesehatan secara terperinci dengan melakukan penyesuain dengan kondisi setempat. Protokol Kesehatan dimaksudkan sebagai panduan umum bagi Peserta dan Penyelenggara Kegiatan Pengabdian Masyarakat. Protokol ini 
merupakan bagian dari keseluruhan kebijakan untuk mewujudkan keselamatan pekerjaan konstruksi dalam kegiatan PKM adalah keselamatan dan kesehatan kerja; keselamatan publik; dan keselamatan lingkungan dalam setiap tahapan penyelenggaraan konstruksi (life cycle of building and infrastructure development). Protokol ini berlaku di pekerjaan konstruksi yang diselenggarakan oleh Jurusan Teknik Elektro Politeknik Negeri Bali. Masingmasing pihak pemangku kepentingan di kegiatan PKM wajib menindaklanjuti protokol ini sesuai dengan situasi yang berkembang di lapangan.

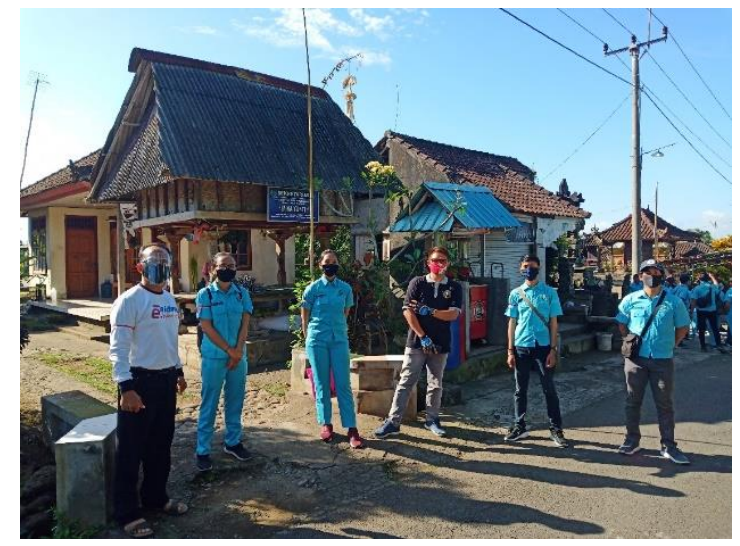

Gambar 1. Setelah Mendapat Pengarahan

Satgas Covid19 (Dengan Pita Merah-

Putih) Siap Bertugas

Untuk melaksanakan protokol kesehatan dalam rangka PKM ini maka dilakukan pembentukan satgas pencegahan covid-19. Peserta/ Penyelenggara Bersama-sama wajib membentuk Satuan Tugas Pencegahan covid-19. Satuan Tugas tersebut berjumlah paling sedikit 5 (lima) orang terdiri dari Ketua merangkap anggota mewakili penyelenggara dan 4 (empat) Anggota yang mewakili peserta. Satuan Tugas memiliki tugas, tanggung jawab dan kewenangan melakukan: sosialisasi, (ii) edukasi, (iii) promosi Teknik, (iv) metoda pencegahaan COVID-19 dan (v) pemeriksaan (examination) potensi terinfeksi kepada semua orang pelaksana, peserta dan tamu proyek.

Untuk dapat melaksanakan tugasnya, satgas pencegahan covid-19 dilengkapi dengan fasilitas kesehatan di lapangan.

Penyelenggara menginventarisir fasilitas kesehatan yang terdekat dari lapangan dilengkapi dengan sarana kesehatan yang memadai, seperti: tabung oksigen, pengukur suhu badan (thermoscan), pengukur tekanan darah, obat-obatan, dan petugas medis. Penyelenggara dan peserta wajib berkoordinasi atas ketersediaan fasilitas pengukur suhu badan (thermoscan), pencuci tangan dengan sabun disinfektan (hand sanitizer), tissue, masker di lokasi PKM untuk pelaksana, peserta dan tamu. 


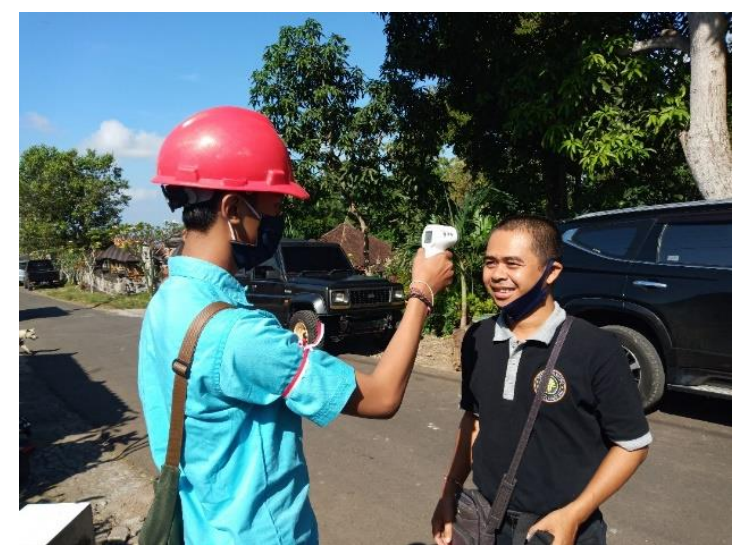

Gambar 2. Pengukuran Suhu Badan

Dalam melaksanakan pencegahan dilapangan, satgas melakukan tugastugasnya seperti diuraikan berikut ini : (1) Satuan Tugas memasang poster (flyers) baik digital maupun fisik tentang himbauan/ anjuran penegahan COVID19, seperti mencuci tangan, memakai masker, untuk disebarluaskan atau dipasang di tempat-tempat strategis di lokasi PKM. (2) Satuan Tugas harus menyampaikan penjelasan, anjuran, kampanye, promosi teknik pencegahan COVID19 dalam setiap kegiatan penyuluhan $\mathrm{K}_{3}$ pagi hari (safety moming talk). (3) Satuan Tugas melarang seseorang yang sakit dengan indikasi suhu lebih dari 38 derajat Celcius datang ke lokasi PKM. (4) Petugas melaksanakan pengukuran suhu tubuh kepada seluruh penyelenggara, peserta dan tamu setiap pagi, siang dan sore. (5) Penyemprotan disinfektan di tempat pelaksanaan PKM sebelum dan setelah PKM dilaksanakan. (6) Penyelenggara, peserta dan tamu wajib menyediakan dan menggunakan masker secara mandiri serta sedapat mungkin menggunakan pelindung wajah. (7) Penyelenggara, peserta dan tamu wajib mencuci tangan saat sampai, dan pulang, serta diharapkan secara rutin untuk mencuci tangan di air yang mengalir dengan sabun. (8) Dalam melaksanakan kegiatan wajib menjaga jarak minimal 1 meter, jika dibutuhkan pekerjaan dilakukan lebih dari satu orang, sehingga jarak 1 meter tidak dapat dipenuhi, maka semua orang yang terlibat dalam pekerjaan tersebut wajib menggunakan masker dan pelindung wajah bening. (9) Satgas melakukan pengawasan secara intensif, atas perilaku Penyelenggara, peserta dan tamu yang potensial menimbulkan penularan. Apabila ditemukan penyelenggara, peserta dan tamu di lapangan PKM terpaparvirus COVID19, Satuan Tugas dibantu Petugas melakukan evakuasi dan penyemprotan disinfektan pada tempat, fasilitas, pegangan dan peralatan kerja di lokasi PKM. 


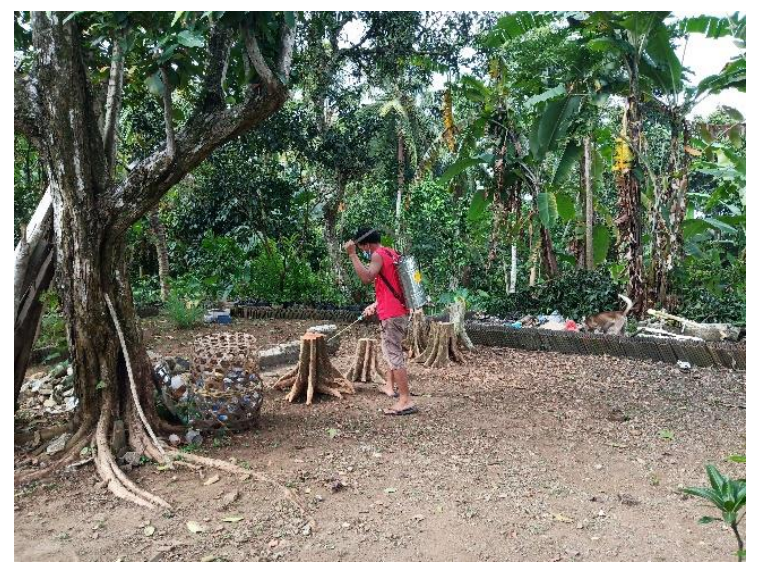

Gambar 3. Penyemprotan Disinfectan oleh Masyarakat Setelah Pelaksanaan

\section{PKM}

Sebelum dilakukan pekerjaan konstruksi pemasangan instalasi pemanas air bak pembenihan ikan, terlebih dahulu dilakukan penjelasan tentang, peralatan yang akan dipasang. Penjelasan diberikan kepada peserta, dan masyarakat menyangkut jenis-jenis alat, spesifikasi, gambar konstruksi, cara pemasangan, pengoperasian dan pemeliharaan. Dipilihnya pembangkit listrik tenaga surya (PLTS) untuk kegiatan PKM ini, karena PLTS merupakan salah satu sumber energi yang ramah lingkungan (Suhendar dkk., 2016:15). Dengan demikian pemilihan sumber energi ini merupakan implementasi atas ditetapkannya Politeknik Negeri Bali sebagai Pusat Unggulan Teknologi Berbasis Green Tourism.

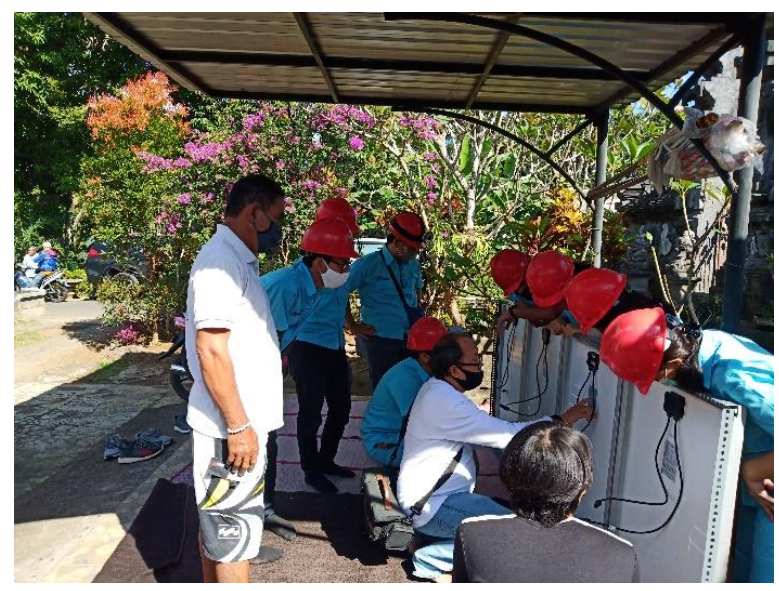

Gambar 4. Penjelasan oleh Dosen

Setelah dilakukan penjelasan dan tanya jawab dilanjutkan pekerjaan konstruksi. Dalam pekerjaan ini 4 buah panel surya dihubungkan secara seri dan paralel, sehingga konstrusi ini menghasilkan tegangan nominal 24 Volt. Hal ini dilakukan untuk menghasilkan daya yang besar melalui instalasi beberapa solar panel yang kecil (Anwar dkk., 2016:59-63; Rinna dkk., 2019:1726). Masing-masing sel surya memiliki tegangan nominal sebesar 12 Volt.

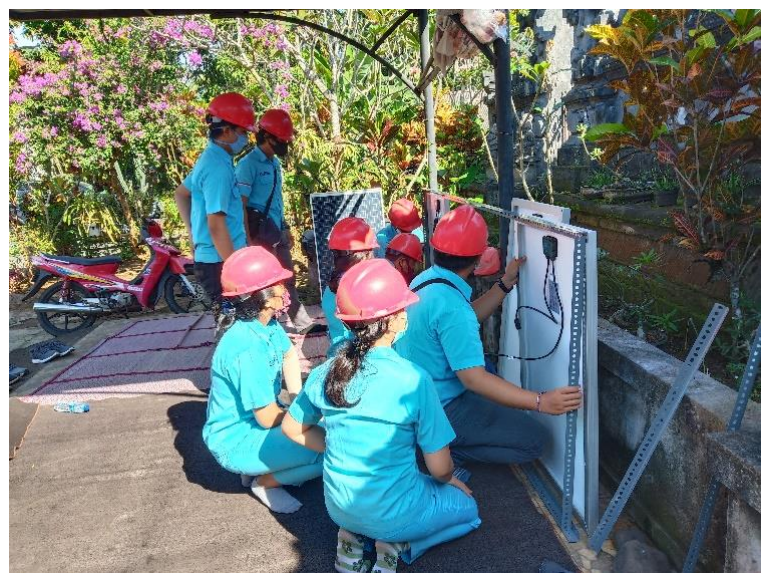

Gambar 5. Mahasiswa Sedang Merakit Pemasangan Panel Surya

Empat buah panel surya ditempatkan dalam sebuah rangka besi 
sikut. rangka ini dibentuk sedemikian rupa, sehingga sesuai dengan ukuran solar panel. Solar panel ini diikat dengan menggunakan baut. Kabelnya didihubungkan secara seri terlebih dahulu untuk dua panel, kemudian hasil hasil hubung seri ini dibungkan paralel dengan dua panel lainnya.

Sebelum ditempatkan dalam panel, pengendali suhu otomatis yang berbasis Arduino terlebih dahulu diprogram. Pemrograman dilakukan untuk menentukan batas temperatur terbawah pemanas mulai bekerja dan batas temperatur atas pemanas harus padam. Dalam pemrograman ini seting temperatur bawah adalah sebesa 25 derajat celcius dan batas temperatur atas di atas 30 derajat celcius. Nilai seting temperatur tersebut diketahui dari referensi yang ada dan seiring arahan petugas penyuluh Dinas Perikanan Kabupaten Tabanan yang juga hadir pada saat pelaksanaan PKM. Controller Arduino ini menggunakan tegangan 12 volt, akan menggerakkan relay kontaktor dengan tegangan 12 volt. Relay kontaktor ini akan menghidupkan dan mematikan lampu pemanas air bak pembenihan sesuai perintah kontroler Arduino.

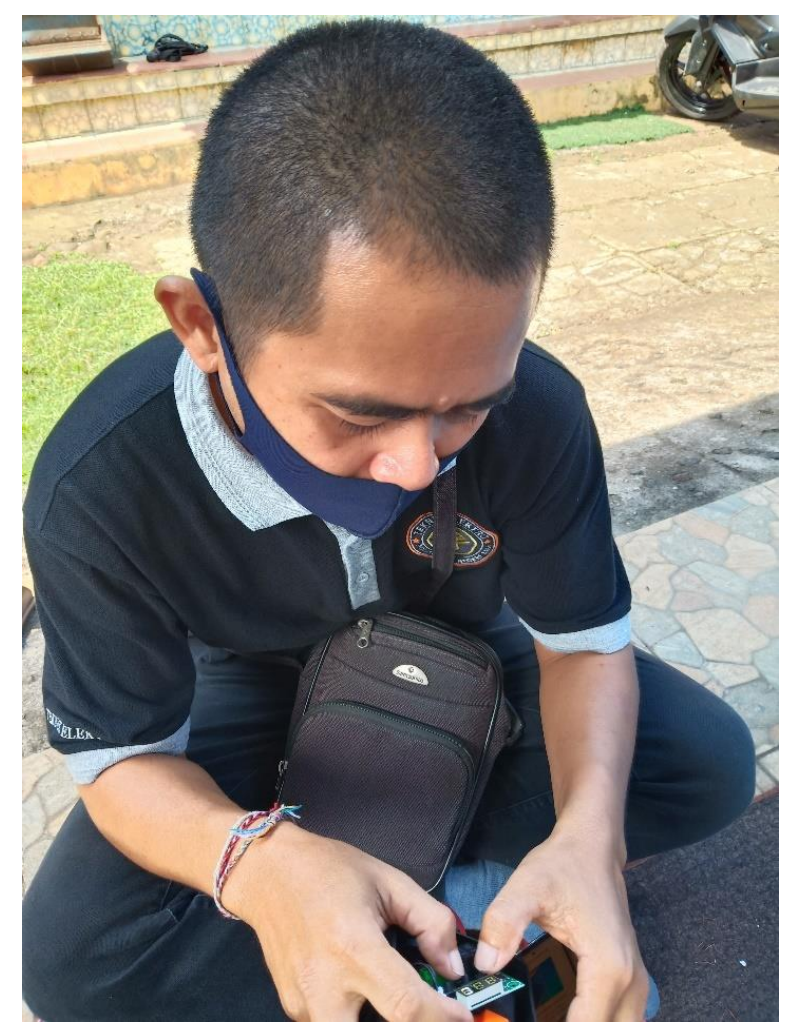

Gambar 6. Pemrograman Thermo Controller Arduino

Dalam PKM ini dibagi menjadi beberapa tim. Tim lainnya ada juga yang sedang memasang instalasi kabel, panel control dan aki. Kabel yang digunakan untuk menyalurkan energi listrik dari panel surya ke panel control menggunakan kabel NYY 2x6 mm2. Sedangakan dari panel control ke aki dipasang kabel NYAF 6 mm2. Untuk kabel instalasi ke lampu pemanas menggunakan kabel NYY 2x2,5 mm2. Lampu yang digunakan adalah lampu halogen 12 volt 50 watt. 


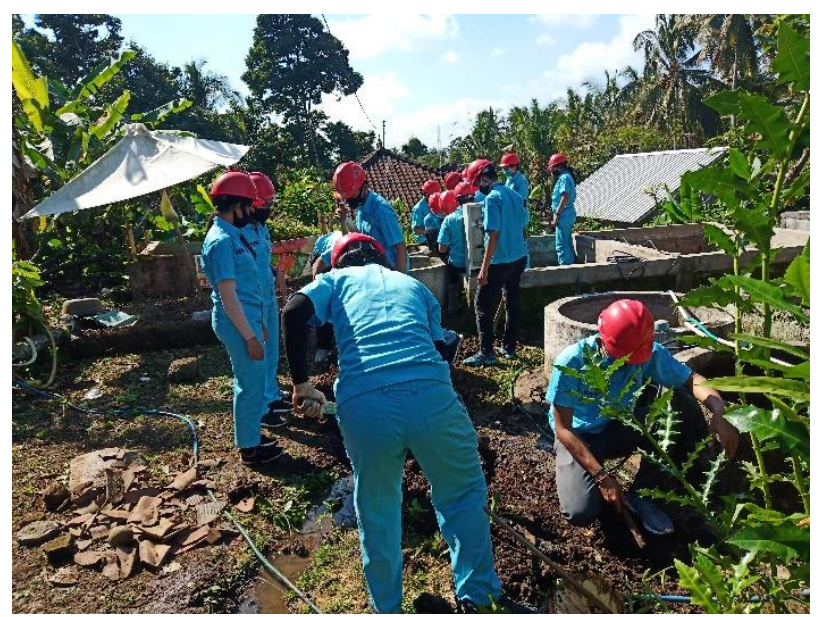

Gambar 7. Penanaman Kabel Power Dan

Pemasangan Panel Control

Proses pemasangan instalasi pemanas bak pembenihan ikan berbasis Arduino dan PLTS ini juga ditinjau oleh Prebekel Desa Lumbung. Peninjauan ini dilakukan sebagai wujud apresiasi terhadap kegiatan ini yang telah melibatkan masyarakat setempat dari kelompok pembudidaya ikan "Mina Yukti”. Dalam proses konstruksi telah terjadi transfer ilmu pengetahuan dari para dosen kepada para peserta PKM ini.

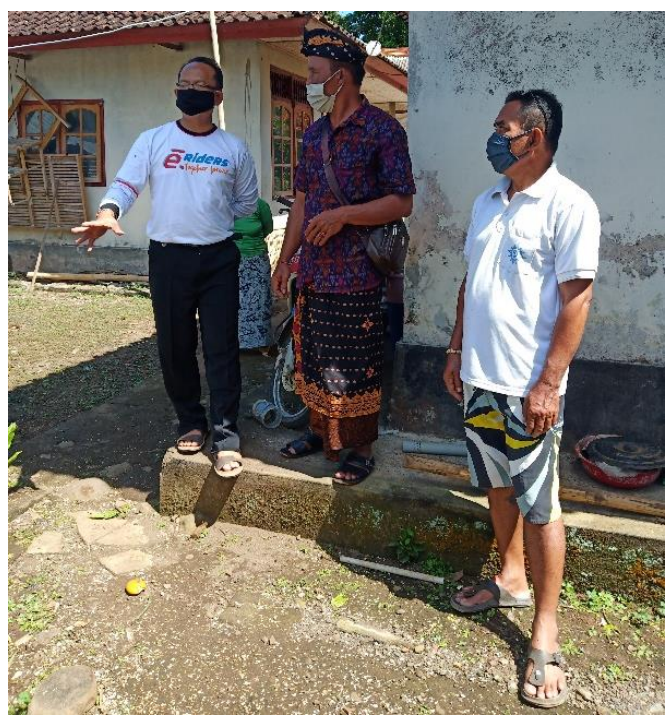

Gambar 8. Perbekel Desa Lumbung Meninjau Pelaksanaan PKM
Setelah proses konstruksi pemasangan instalasi selesai maka tercapailah luaran yang berupa instalasi pemanas air bak pembenihan ikan berbasis Arduino dan PLTS, dan telah terbukti mampu mengkondisikan temperatur air di dalam bak pembenihan ikan. Untuk memastikan bahwa luaran PKM ini telah berfungsi dengan baik dilakukan pembersihan, testing dan komisioning. Kegiatan ini ini dilakukan oleh teknisi bersama masyarakat anggota kelompok pembudidaya ikan "Mina Yukti”. Komisioning dilakukan dengan melakukan pengukuran tegangan masuk dari panel surya yang diperoleh saat itu sebesar 42 volt. Dilanjutkan dengan arus charger yang mencai angka 7,1 Amper. Tegangan yang hasilkan oleh charger controller adalah sebesar 27,6 volt. Lampu dicoba dinyalakan untuk memanaskan air, dan terbukti temperatur air antara 25 sampai dengan 30 derajat celcius dapat tercapai.

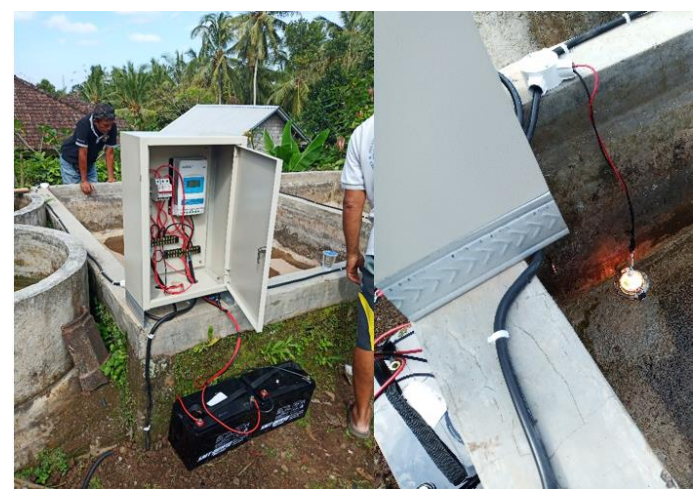

Gambar 9. Testing dan komisioning Panel Control PLTS, Instalasi

Penerangan dan Aki 
Setelah testing dan komisoning selesai dilakukan, dan dipastikan peralatan telah beroperasi dengan baik, dilanjutkan dengan serah terima. Serah terima hasil kegiatan PKM diserahkan dari Politeknik Negeri Bali (PNB) kepada masyarakat. PNB dalam kesempatan tersebut diwakili oleh Sekretaris Jurusan Teknik Elektro. Dari unsur masyarakat diwakili oleh Prebekel Desa Lumbung, sebagaimana ditunjukkan dalam gambar di bawah ini. Tampak di latar belakang gambar di bawah ini cell surya yang telah dipasang dan berfungsi dengan baik.

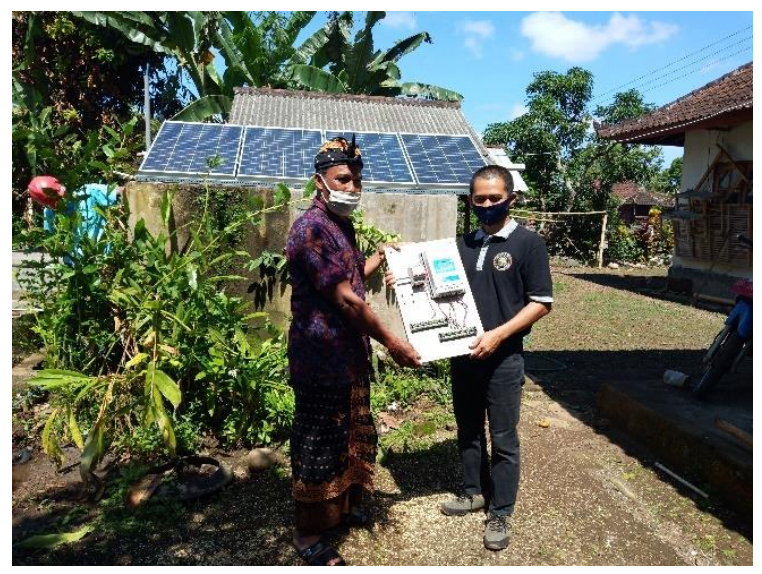

Gambar 10. Penyerahan Hasil PKM oleh

Sekjur T. Elektro kepada Prebekel

Setelah instalasi ini dioperasikan, dilanjutkan dengan penebaran larva ikan untuk ditetaskan hingga siap disemai di kolam pembesaran. Selesainya instalasi ini bertepatan dengan telah dimulainya musim dingin, sehingga instalasi ini langsung dimanfaatkan oleh kelompok pembudidaya ikan "Mina Yukti". Setelah pemasangan instalasi ini, kelompok ini telah melakukan panen bibit ikan pada akhir Agustus dan pertengahan oktober. Waktu panen ini adalah 45 hari setelah tebar larva seperti ditunjukkan dalam di bawah ini. Masa waktu 45 hari ini sama dengan waktu panen tat kala musim panas. Pemasangan instalasi pemanas air ini telah berhasil membantu pengadaan bibit ikan walaupun pada musim dingin. Jika sebelumnya kelompok pembudidaya ikan tidak dapat melakukan panen bibit ikan diantara bulan Juli sampai dengan Nopember.

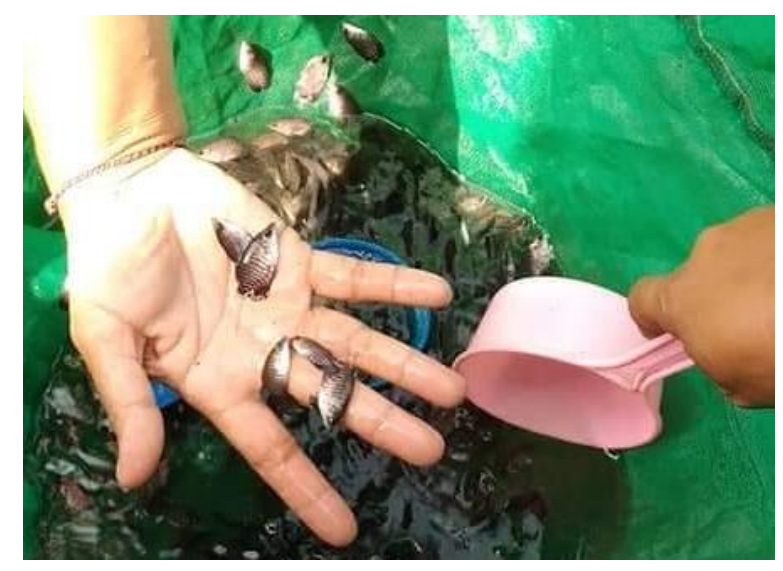

Gambar 11. Hasil Panen Benih Ikan Siap

\section{Semai}

Pelaksanaan kegiatan PKM ini dapat berjalan lancar didorong oleh beberapa hal antara lain : (1) tersedianya sumber daya manusia yang memahami tentang Teknik penyediaan energi listrik dan konversi energi, serta tersedianya sumber daya manusia yang memahami tentang pembenihan ikan yang peduli terhadap permasalahan yang dihadapi oleh kelompok pembudidaya ikan "Mina Yukti”; (2) dukungan aparat setempat 
baik dari Prebekel Desa Lumbung dan petugas penyuluh lapangan dari Dinas Perikanan Kabupaten Tabanan; tersedianya anggaran untuk melaksanakan kegiatan ini dari DIPAPNB Tahun 2020; (4) tersedianya material-material yang dibutuhkan untuk kegiatan ini, walau sebagian mendatangkan dari Jakarta; (5) sebagai institusi pendidikan vokasi, Politeknik Negeri Bali memiliki peralatan yang cukup untuk melaksanakan konstruksi pemasangan instalasi pemanas air bak pembenihan ikan berbasis Arduino dan pembangkit listrik tenaga surya; (6) pengalaman yang dimiliki oleh para Dosen Teknik Elektro dalam penelitian dan pengajaran memberikan sumbangsih yang luar biasa besar untuk merencanakan, melaksanakan dan mengawasi metode pelaksanaan kegiatan ini, sehingga berjalan lancar.

Ditengah hadirnya berbagai faktor pendorong, dalam PKM ini terdapat juga faktor penghambat antara lain: (1) masih mahalnya biaya pengadaan solar sel; (2) terbatasnya anggaran yang dimiliki untuk melaksanakan kegiatan ini. Program PKM ini hanya mampu memasang instalasi di 1 petak bak pembenihan. Sehingga masih terdapat 4 bak pembenihan yang belum dipasang instalasi pemanas. Berikut disajikan foto bak pembenihan ikan milik kelompok budi daya ikan "Mina Yukti".

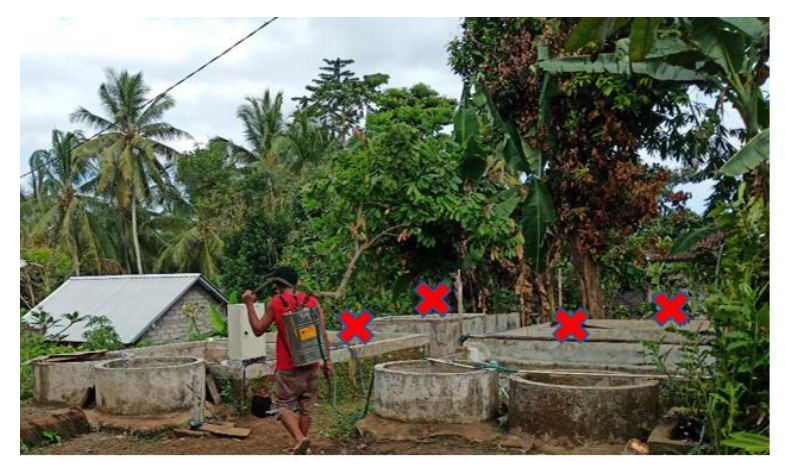

Gambar 12. Bak Pembenihan Yang Belum Dipasang Instalasi Pemanas Air (Silang Merah)

\section{PENUTUP}

\section{Simpulan}

Berdasarkan uraian hasil dan pembahasan dapat disimpulkan bahwa dimasa pandemi ini terjadi permasalahan ketahanan pangan yang dapat ditanggulangi dengan sentuhan teknologi.

Dimasa pandemi yang bertepatan dengan musim dingin mengancam ketahanan pangan kelompok pembudidaya ikan "mina yukti", karena pada musim dingin ini kerap gagal panen benih ikan.

Pemasang instalasi pemanas air bak pembenihan ikan berbasis Arduino dan pembangkit listrik tenaga surya merupakan Langkah tepat yang dilakukan dalam kegiatan pengabdian kepada masyarakat oleh Jurusan Teknik Elektro Politeknik Negeri Bali. 
Luaran kegiatan PKM berupa instalasi pemanas air bak pembenihan ikan berbasis Arduino dan pembangkit listrik tenaga surya, telah terbukti berhasil guna, karena pada musim dingin panen benih ikan tetap dapat dilakukan, bahkan telah dua kali panen pada musim dingin.

Ketersediaan sumber daya manusia, anggaran, material, peralatan, dan mesin-mesin serta metode pelaksanaan yang layak, menjadi faktor pendorong keberhasilan pelaksanaan kegiatan PKM ini.

Keterbatasan anggaran menjadi faktor penghambat untuk menuntaskan kegiatan PKM ini, karena masih terdapat 4 bak pembenihan yang belum dipasang instalasi pemanas air.

\section{Saran}

Berdasarkan hasil pelaksanaan PKM ini, maka dapat disarankan bahwa, untuk menjamin ketahanan pangan dalam hal ketersediaan ikan, maka perlu dilakukan pemasangan secara masal instalasi pemanas bak pembenihan ikan berbasis arduino dan pembangkit listrik tenaga surya serupa ini, karena luaran kegiatan ini telah terbukti meningkatkan ketahanan pangan di Desa Lumbung, khususnya kelompok pembudidaya ikan "Mina Yukti”, karena panen berhasil pada saat musim dingin, luaran kegiatan ini merupakan contoh pemanfaatan energi yang ramah lingkungan.

Perlu dipertimbangkan alternatif sumber energi lain, yang lebih ramah lingkungan dan murah.

Pemerintah perlu menyiapkan anggaran pengabdian yang lebih besar untuk mempercepat pemanfaatan teknologi dibidang ketahanan pangan, sehingga bak pembenihan ikan yang lain dapat segera dipasang instalasi pemanas air.

\section{Ucapan Terima Kasih}

Pada kesempatan yang baik ini disampaikan ucapan terimakasih kepada Yang terhormat Direktur Politeknik Negeri Bali yang telah mendanai kegiatan Pengabdian kepada Masyarakat ini. Yang terhormat Kepala P3M Politeknik Negeri Bali yang telah menyetujui pelaksanaan kegiatan Pengabdian kepada Masyarakat ini. Kepada semua pihak yang telah membantu suksesnya kegiatan ini.

\section{DAFTAR PUSTAKA}

Alfin Febrian Basundoro, Fadhil Haidar Sulaeman. 2020. Meninjau Pengembangan Food Estate Sebagai Strategi Ketahanan Nasional Pada Era Pandemi Covid19. Jurnal Kajian Lemhanas RI, Vol 8 No 2, Hal 28-42. 
https://jurnal.lemhannas.go.id/ind

ex.php/jkl/issue/view/13.

Anggalih Bayu Muh. Kamim. 2020.

Wabah Virus Korona Dan

Momentum Evaluasi Rezim

Ketahanan Pangan Di Indonesia

(Covid-19 Pandemi And

Momentum Of Food Security

Evaluation In Indonesia). Jurnal

Kependudukan Indonesia | Edisi

Khusus Demografi dan COVID-19,

Juli 2020 | 87-92 p-ISSN : 1907-

2902 (Print) e-ISSN : 2502-8537

(Online).

Anwar Ilmar Ramadhan, Ery Diniardi,

Sony Hari Mukti. 2016. Analisis

Desain Sistem Pembangkit Listrik

Tenaga Surya Kapasitas 50 WP.

TEKNIK, p-ISSN 0852-1697, e-

ISSN: 2460-9919, 37(2), 2016, 59-

63 doi:10.14710/teknik.v37n2.9011

Copyright

(C) 2016.

http://ejournal.undip.ac.id/index.p

hp/teknik.

Khaidir Hakam Gilang Ahmad. 2019.

Sistem Kontrol Temperatur, $\mathrm{Ph}$,

Dan Kejernihan Air Kolam Ikan

Berbasis Arduino UNO. Jurnal

Teknik Elektro, Vol. 8 No. 2.

Muarif. 2016. Karakteristik Suhu

Perairan di Kolam Budidaya

Perikanan. Jurnal Mina Sains ISSN:
2407-9030 Volume 2 Nomor 2, Oktober $2016 \quad 96-1001$. https://ojs.unida.ac.id/jmss/article /view/444/253.

Rinna Hariyati ; Muchamad Nur Qosim; Aas Wasri Hasanah. 2019. Konsep Fotovoltaik Terintegrasi On Grid dengan Gedung STT-PLN. Energi dan Kelistrikan: Jurnal Ilmiah Vol. 11, No. 1, Januari - Juni 2019, PISSN 1979-0783, E-ISSN 26555042. https://stt-pln.ejournal.id/energi/article/download $\angle 394 / 396$.

Sa'dianoor, Syamsul Maarif, Sobar Sutisna, Eddy Saptono, Achsannul Hakim, dan Zainuddin. 2020. Kearifan Masyarakat Pegunungn Meratus Kabupaten Hulu Sungai Tengah Menggunakan Makanan Lokal Sebagai Bagianketahanan Nasioal Di Masa Pandemi. Jurnal Kajian Lemhanas RI, Vol 8 No 2, Hal 76-90.

https://jurnal.lemhannas.go.id/ind ex.php/jkl/issue/view/13.

Suhendar, Budi Raharjo, Alimuddin , Hady Sutjipto. Studi Potensi Lahan Dan Area Perumahan Untuk Implementasi Pembangkit Listrik Tenaga Surya (Plts) Di Wilayah Serang Dan Cilegon Banten. Jurnal Ecotipe, Volume 3, Nomor 1, April 
2016 ISSN 2355-5068, hal : 14-24.

http://journal.ubb.ac.id/index.php

Lecotipe/article/download/26/22.

Trisasongko Widianto. 2020. Protokol

Pencegahan Covid-19 di Proyek

Konstruksi. Direktur Jenderal Bina

Konstruksi, Kementrian Pekerjaan
Umum dan Perumahan Rakyat. https://covid19.kemkes.go.id/proto kol-covid-19/protokol-pencegahancovid-19-di-proyekkonstruksi/\#.X.X 533 rYgzbIU. 